\title{
Comparison Between Cold/Hot Smart Water Flooding in Sandstone Reservoirs
} Hasan N Al-Saedi ${ }^{*}$, Ariel Williams ${ }^{2}$, Ralph E Flori ${ }^{3}$

${ }^{1}$ Missouri University of Science and Technology/Missan Oil Company, Missouri, USA

${ }^{2}$ Politecnico Di Torino, Turin, Italy

${ }^{3}$ Missouri University of Science and Technology, Rolla, Missouri, USA

\begin{abstract}
The incremental oil recovery has been investigated and approved by many laboratory and field projects using water flooding in tertiary stage. The salinity of the injected water is an important factor observed by many researchers. The more salinity decreases the more oil recovery obtained. The investigations on the hot low salinity water flooding have been conducted by many researchers and they found out that it is useful for increasing oil recovery especially heavy oil due to reducing oil viscosity and make it easy to produce to the surface. The thermal expansion of water plays an important role in the incremental oil recovery mechanism, reducing the density of the injected water relative to the aquifer water. This reduces mixing; minimizing thermal loses to the aquifer. Hot water flooding may also increase the economic life of individual wells by as much as a factor of two. Smart water was also used to alter the reservoir wettability and increase oil recovery by manipulating the divalent cations in the injected water. In this study, we used hot and cold smart water and injected both into the sandstone saturated with crude oil in order to investigate the important role of smart water itself and hot smart water. The systematic results showed that changing some cations in the injected brines was better than to spend more money to heat the smart water. The divalent cations $\mathrm{Ca}^{2+}$ and $\mathrm{Mg}^{2+}$ were the most effective component in the smart water. In this study, we also studied the pH effect of the cold/hot smart water effluent smart water EOR.
\end{abstract}

Keywords: Smart water flooding; Enhanced oil recovery; Thermal enhanced oil recovery

\section{Introduction}

Eastern Kansas oil field contains heavy oil that is produced via rod sucker pumps. The daily production from Bartlesville Sandstone reservoir is around $500 \mathrm{bbl} /$ day with a higher water cut. Such reservoirs have a low temperature and the oil viscosity of several hundreds of centipoise. The mobility ratio is quite different between the water and the heavy oil and if a conventional water flooding would be conducted, the oil recovery could be low. A higher temperature of water flooding, prompt to reduce the oil viscosity. The hot injected water also could reduce the unequal viscosity of the water and the oil in the heated zone, and in turn, the sweep efficiency could be improved.

In this work, we injected smart water because of its results in increasing oil recovery according to many labs works and pilot based on the mechanisms that propose and qualify the effectiveness of smart water flooding such as: (i) Multicomponent ion exchange [1], (ii) Double-layer expansion [2], (iii) Reduction in interfacial tension and increased pH [3] (iv) Fines mobilization [4], (v) Mineral dissolution [5] (vi) Organic material desorption from the clay surface [6], (vii) Cation exchange on quartz surface [7] (viii) Desorption of organic materials from quartz surface [8].

In the case of using thermal EOR techniques, the heat provided to the reservoir could absolutely reduce the oil viscosity and increase oil recovery. The economic overview, on the other hand, the least expensive thermally technique is hot water flooding based on oil recovery [9]. In this work, a combined chemical and thermal technology was applied on Bartlesville Sandstone cores to find a feasible, cost-effective EOR solution to increase oil recovery from heavy oil reservoirs without using high energy methods such as thermal techniques.

\section{Experimental Section}

\section{Porous media}

Core samples were taken from the Bartlesville Sandstone reservoir located in east Kansas. The cores description is listed in Tables 1 and 2.

\section{Brines and crude oil}

Reagent-grade salts were prepared with deionized water to make FW and smart water. The compositions of brines are listed in Table 1. A reservoir crude oil was delivered by Colt Energy from Bartlesville Sandstone reservoir. The oil viscosity is $\sim 600 \mathrm{cp}$ and density 0.83 at $20^{\circ} \mathrm{C}$.

\section{Core preparation and flooding}

The experimental setup is shown in Figure 1. The cores first cleaned with toluene. The cores were then evacuated and saturated under vacuum in the FW. The same FW was used to measure the permeability. The cores were pre-aged in heavy crude oil for three weeks at $90^{\circ} \mathrm{C}$. The water flooding was conducted at reservoir temperature $90^{\circ} \mathrm{C}$. FW was injected into the cores until residual oil saturation was reached. After that, smart water was injected until no more oil was produced and injection pressure stabilized. The cores were saturated with the same

\begin{tabular}{|c|c|c|}
\hline Elements & FW & Smart Water \\
\hline $\mathrm{Na}^{+}$ & 1.50 & 0.015 \\
\hline $\mathrm{Cl}^{-}$ & 1.675 & 0.01675 \\
\hline $\mathrm{Ca}^{2+}$ & 0.089 & Table 2 \\
\hline $\mathrm{Mg}^{2+}$ & 0.089 & Table 2 \\
\hline TDS & 97.5 & $\sim 1.0$ \\
\hline Salinity & 97500 & $\sim 1000$ \\
\hline
\end{tabular}

Table 1: Brines composition ( $\mathrm{mol} / \mathrm{L})$.

"Corresponding author: Hasan N. Al-Saedi, Missouri University of Science and Technology/Missan Oil Company, Missouri, USA, Tel: +1 800-522-0938; E-mail: hnav36@mst.edu

Received May 10, 2018; Accepted May 23, 2018; Published May 31, 2018

Citation: Al-Saedi HN, Williams A, Di Torino P, Flori RE (2018) Comparison Between Cold/Hot Smart Water Flooding in Sandstone Reservoirs. J Pet Environ Biotechnol 9: 365. doi: 10.4172/2157-7463.1000365

Copyright: (C $2018 \mathrm{Al}-\mathrm{Saedi} \mathrm{HN}$, et al. This is an open-access article distributed under the terms of the Creative Commons Attribution License, which permits unrestricted use, distribution, and reproduction in any medium, provided the original author and source are credited. 
FW and smart water was injected as follows:

RC1: The smart water contains $45 \mathrm{mmol}$ of $\mathrm{Ca}^{2+}$, and the experiment temperature was $25^{\circ} \mathrm{C}$.

RC2: The smart water contains $90 \mathrm{mmol}$ of $\mathrm{Ca}^{2+}$, and the experiment temperature was $85^{\circ} \mathrm{C}$.

RC3: The smart water contains $45 \mathrm{mmol}$ of $\mathrm{Mg}^{2+}$, and the experiment temperature was $25^{\circ} \mathrm{C}$.

RC4: The smart water contains $90 \mathrm{mmol}$ of $\mathrm{Mg}^{2+}$, and the experiment temperature was $85^{\circ} \mathrm{C}$.

\section{Results and Discussion}

Reservoir core (RC1) and RC2 were flooded with smart water

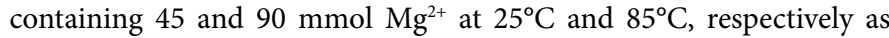
described in Table 2, while both RC3 and RC4 were flooded with smart water containing 45 and $90 \mathrm{mmol} \mathrm{Ca}^{2+}$ at $25^{\circ} \mathrm{C}$ and $85^{\circ} \mathrm{C}$, respectively.

RC1: The temperature of this experiment was set on $25^{\circ} \mathrm{C}$. The core successively flooded with FW and smart water. The volume of the produced oil was collected and logged at the room temperature. The pressure readings were also recorded. The ultimate oil recovery was $54 \%$ of original oil in place (OOIP) after the core flooded with FW (Figure 2). The injection pressure started with 50 psi and rose up to $180 \mathrm{psi}$ and dropped until stabilizing at 41 psi after injecting $2 \mathrm{PV}$ of FW (Figure 3). The incremental oil recovery after switching the injected brine to smart water was $5 \%$ of OOIP (Figure 2). The injection pressure rose up to 64 psi and stabilized at 49 psi (Figure 3 ).

RC2: This core was flooded the same way as RC1 except the smart water containing $90 \mathrm{mmol}$ of $\mathrm{Mg}^{2+}$. The temperature was $85^{\circ} \mathrm{C}$ for both FW and smart water flooding. The oil recovery during secondary water flooding with FW was 57\% (Figure 2), the flooding was stopped after injecting 2 PV of FW. The water injection stopped until no more oil was produced and until the pressure stabilized. During the FW flooding, the pressure started 52 psi. The pressure increased quickly until reaching the maximum reading at $151 \mathrm{psi}$. After the crude oil began to flow out the core, the pressure decreased slowly until stabilizing at 31 psi (Figure 3). Upon switching to smart water, the incremental oil recovery was $2 \%$ of OOIP. The injection pressure increased dramatically until reaching the highest point which was 51 psi and stabilized at that point (Figure 3).

RC3: This core and the following one (RC4) were flooded with smart water containing 45 and $90 \mathrm{mmol}$ of $\mathrm{Ca}^{2+}$ at 25 and $85^{\circ} \mathrm{C}$, respectively.

\begin{tabular}{|c|c|c|c|c|c|c|c|}
\hline Core & Diameter (cm) & Length (cm) & $K(m d)$ & Porosity (\%) & $\begin{array}{c}\mathrm{Ca}^{2+} \text { in the smart } \\
\text { water }\end{array}$ & $\begin{array}{c}\mathrm{Mg}^{2+} \text { in the smart } \\
\text { water }\end{array}$ & $\mathrm{T}\left({ }^{\circ} \mathrm{C}\right)$ \\
\hline $\mathrm{RC} 1$ & \multirow{4}{*}{2.54} & $14.50 \mathrm{~cm}$ & $77 \mathrm{md}$ & $20 \%$ & 0 & 45 & $25^{\circ} \mathrm{C}$ \\
\hline $\mathrm{RC} 2$ & & $14.44 \mathrm{~cm}$ & $71 \mathrm{md}$ & $18 \%$ & 0 & 90 & $85^{\circ} \mathrm{C}$ \\
\hline RC3 & & $14.47 \mathrm{~cm}$ & $82 \mathrm{md}$ & $21 \%$ & 45 & 0 & $25^{\circ} \mathrm{C}$ \\
\hline RC3 & & $14.45 \mathrm{~cm}$ & $75 \mathrm{md}$ & $20.3 \%$ & 90 & 0 & $85^{\circ} \mathrm{C}$ \\
\hline
\end{tabular}

Table 2: Petrophysical properties.

\begin{tabular}{|c|c|c|c|c|c|c|}
\hline Core & FW & Smart & Total & $\mathrm{T}\left({ }^{\circ} \mathrm{C}\right)$ & $\begin{array}{c}\mathrm{Ca}^{2+} \text { in the smart } \\
\text { water }\end{array}$ & $\begin{array}{c}\mathrm{Mg}^{2+} \text { in the smart } \\
\text { water }\end{array}$ \\
\hline $\mathrm{RC} 1$ & 54 & 5 & 59 & $25^{\circ} \mathrm{C}$ & 0 & 45 \\
\hline $\mathrm{RC} 2$ & 57 & 2 & 2 & $85^{\circ} \mathrm{C}$ & 0 & 90 \\
\hline RC3 & 51 & 9 & 9 & $25^{\circ} \mathrm{C}$ & 45 & 0 \\
\hline RC4 & 53 & 1 & 1 & $85^{\circ} \mathrm{C}$ & 90 & 0 \\
\hline
\end{tabular}

Table 3: Oil recovery results.

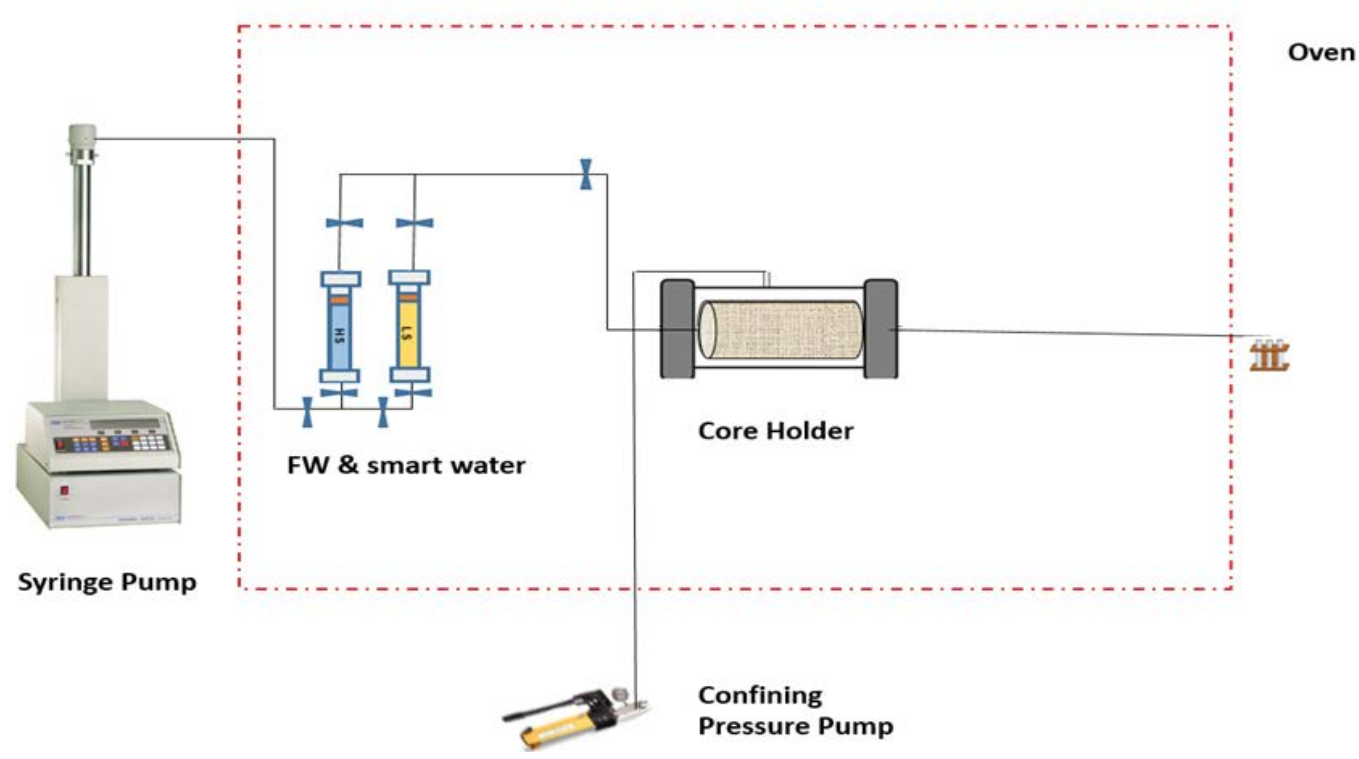

Figure 1: Waterflood experimental setup. 
Citation: Al-Saedi HN, Williams A, Di Torino P, Flori RE (2018) Comparison Between Cold/Hot Smart Water Flooding in Sandstone Reservoirs. J Pet Environ Biotechnol 9: 365. doi: 10.4172/2157-7463.1000365

The experiment temperature is $25^{\circ} \mathrm{C}$ for RC3. The oil recovery with FW was $51 \%$ of OOIP (Figure 4). The injection pressure started with $66 \mathrm{psi}$ and rose up to 160 psi and then stabilized at 52 psi (Figure 5). Upon switching to smart water the improved oil recovery was $9 \%$ of OOIP (Figure 4). The injection pressure stabilized at 59 psi (Figure 5).

RC4: The experiment temperature was set at $85^{\circ} \mathrm{C}$. The same procedure was followed as in previous cores. After injecting $2 \mathrm{PV}$ of $\mathrm{FW}$ the oil recovery was $53 \%$ of OOIP (Figure 4 ). The recovery was improved to $54 \%$ after the injected brine switched to smart water, resulting in a $1 \%$ incremental recovery of OOIP (Figure 4 ). The injection pressure stabilized at 43 psi (Figure 5).

All Cores were similar in FW but different in the experiment temperatures and the injected smart water. Both $\mathrm{RC} 1$ and $\mathrm{RC} 2$ were flooded using 45 and $90 \mathrm{mmol}$ of $\mathrm{Mg}^{2+}$ in the smart water but at $25^{\circ} \mathrm{C}$ and $85^{\circ} \mathrm{C}$.

Increasing concentration of $\mathrm{Mg}^{2+}$ in smart water has the effect on reducing oil recovery during smart water flooding. Comparing $\mathrm{RC} 1$ and RC2, the oil recovery from RC1 by FW was $54 \%$ of OOIP, while it was $57 \%$ of OOIP from RC2. The ultimate oil recovery in RC2 was higher than in RC1 because the higher temperature.

The incremental oil recovery from $\mathrm{RC} 1$ using smart water was $5 \%$ of OOIP, while it was $2 \%$ of OOIP from RC2; i.e., the improved oil recovery decreased by a factor of 2.5 when doubling the concentration of the $\mathrm{Mg}^{2+}$ in the injected smart water even though the temperature was higher for RC2. Similarly, comparing RC3 with RC4, the oil recovery was $51 \%$ of OOIP for RC3 with FW flooding, while it was 53\% for RC4 also due to extra heat. The incremental oil recovery using smart water flooding was $9 \%$ of OOIP for RC3, while it was only $1 \%$ of OOIP for RC4; i.e., the improved oil recovery increased by a factor of 9 if we reduced the concentration of the $\mathrm{Ca}^{2+}$ in the injected smart water although the temperature was ambient temperature. Increasing the divalent cations in the injected smart water led to decrease the adsorption of the organic
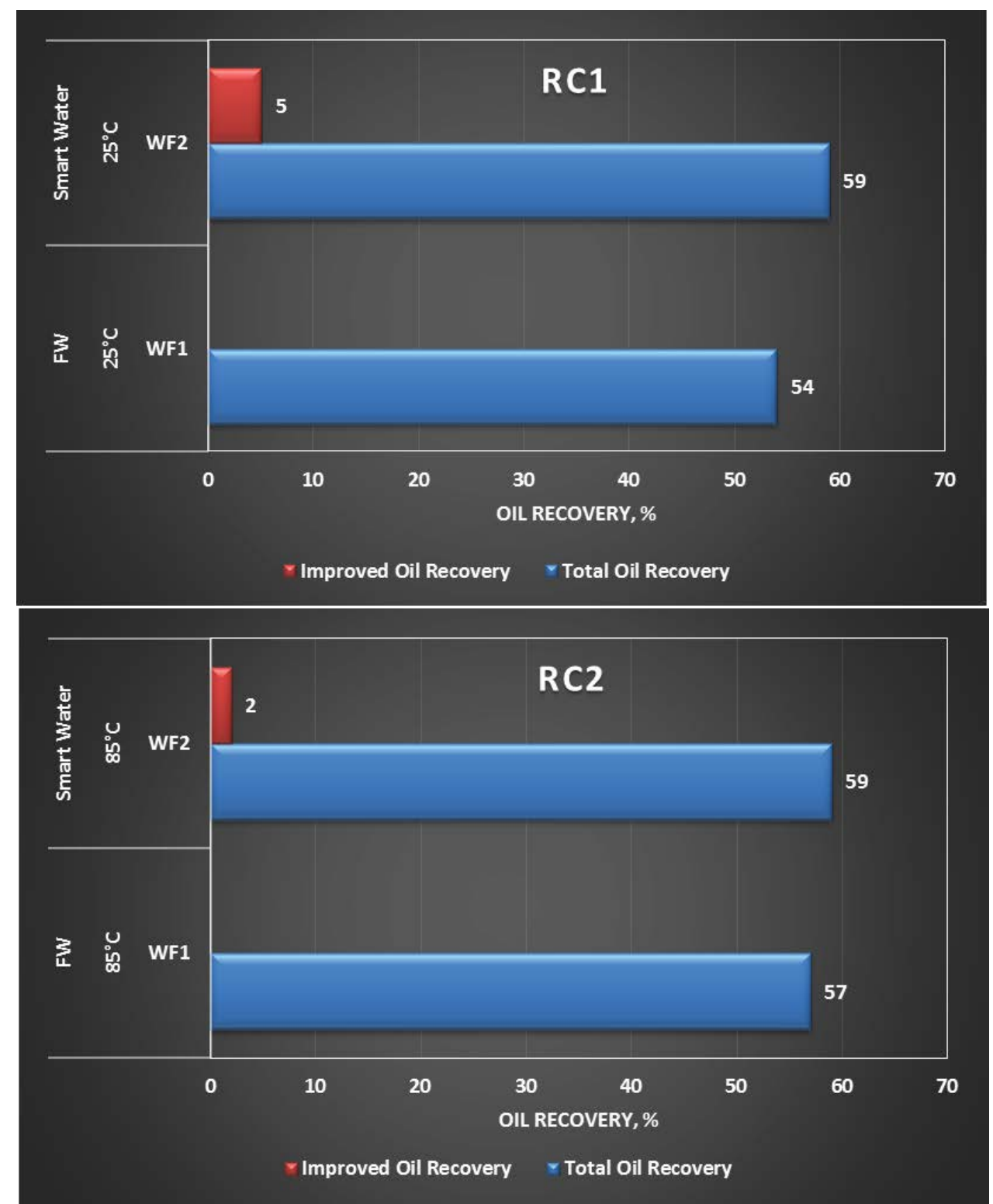

Figure 2: Total and incremental oil recovery for RC1 and RC2. 


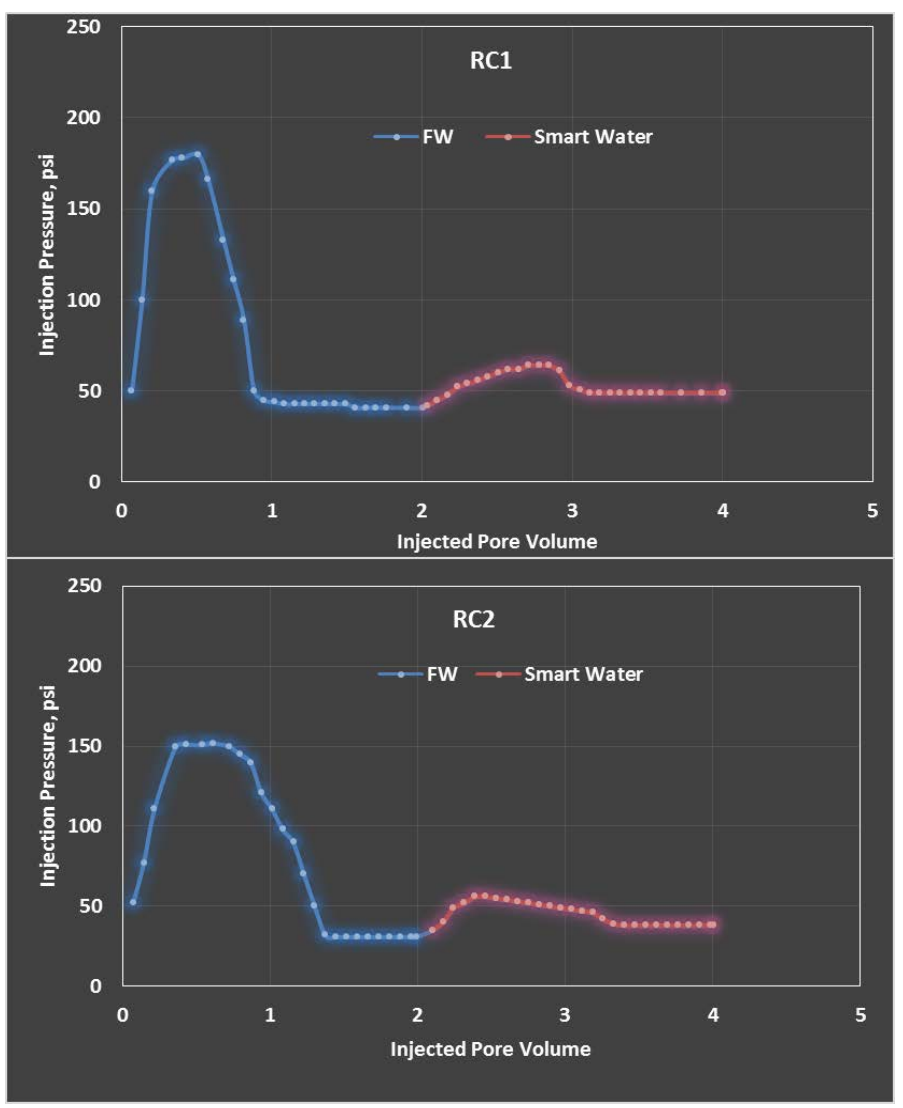

Figure 3: FW and smart water Injection pressure for RC1 and RC2.
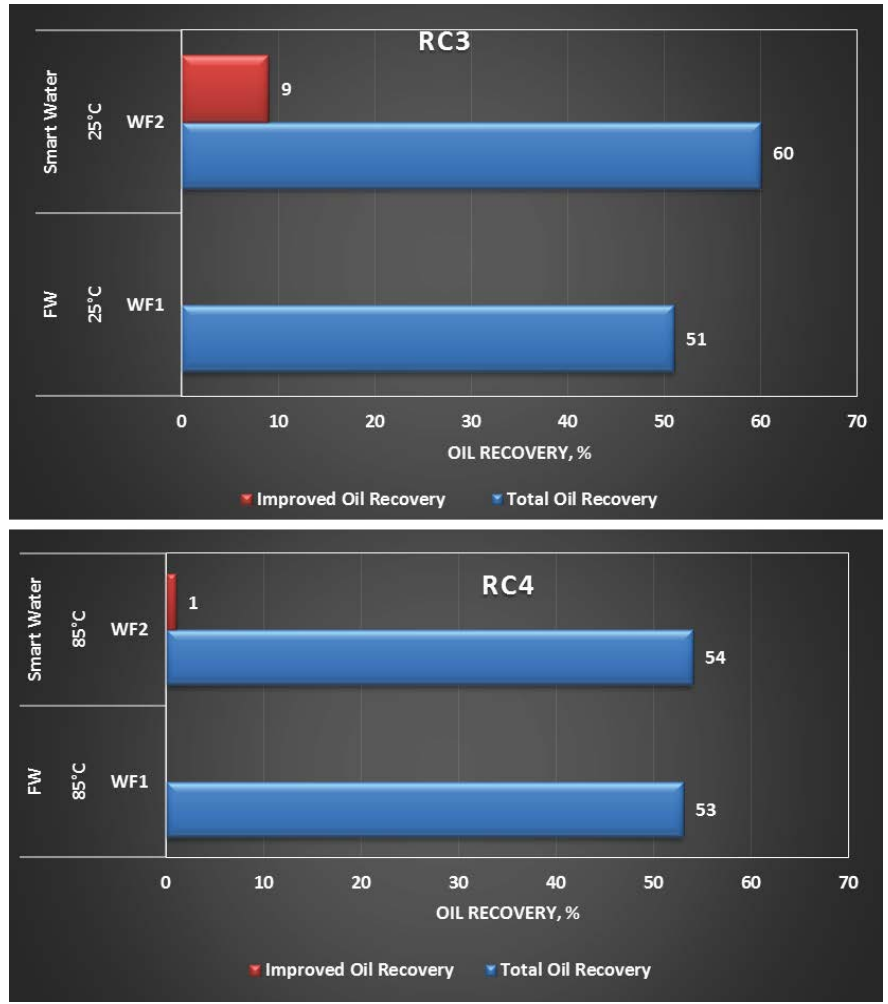

Figure 4: Total and incremental oil recovery for RC3 and RC4. 
Citation: Al-Saedi HN, Williams A, Di Torino P, Flori RE (2018) Comparison Between Cold/Hot Smart Water Flooding in Sandstone Reservoirs. J Pet Environ Biotechnol 9: 365. doi: 10.4172/2157-7463.1000365

Page 5 of 6

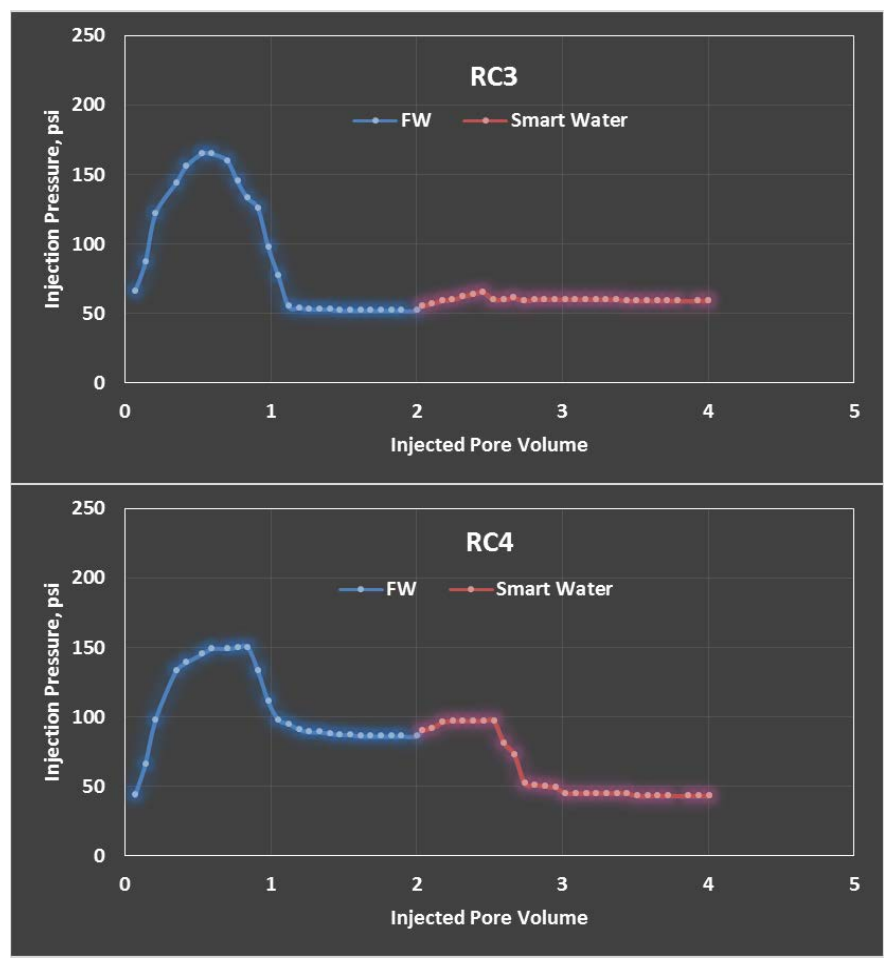

Figure 5: FW and smart water Injection pressure for RC3 and RC4.

material, and in turn, the rock became too water-wet for observing smart water effect. During FW flooding, comparing all the cores in this work the higher the temperature, the higher the oil recovery. Using hot water improves the mobility ratio due to reducing the oil phase viscosity compared with cold water. Thermal expansion of water plays an important role in injecting hot water, the lower density of hot water reduces thermal loses to the aquifer and speeds up the propagation of the temperature front through the reservoir.

The effect of increasing the temperature to $85^{\circ} \mathrm{C}$ with a double $\mathrm{Mg}^{2+}$ concentration in smart water (RC2) is the same as applying $25^{\circ} \mathrm{C}$ with a smart water containing a half concentration of $\mathrm{Mg}^{2+}(\mathrm{RC} 1)$.

Increasing temperature to $85^{\circ} \mathrm{C}$ when smart water has double $\mathrm{Ca}^{2+}$ concentration (RC4) is a worse scenario than using $25^{\circ} \mathrm{C}$ with an smart water contains a half concentration of $\mathrm{Ca}^{2+}(\mathrm{RC} 3)$. The fuel consumption using high temperature could be replaced chemically by controlling the divalent cations concentration. The fuel consumption could be more feasible when controlling the water chemistry. The good example for that is RC3 when lowering the $\mathrm{Ca}^{2+}$ to the half and also (RC1) when lowering the $\mathrm{Mg}^{2+}$ to the half. Applying ambient temperature with reducing $\mathrm{Ca}^{2+}$ concentration to a half provided a higher oil recovery among all the other scenarios (60\% of OOIP). Table 3 shows the summary of the results.

\section{Conclusion}

Increasing the temperature of the injected water reduces the viscosity contrast between oil and water in the heated region. This can improve the sweep efficiency. Heating the oil using hot water could reduce the oil viscosity and in turn increase oil recovery.

Hot water flooding may also increase the economic life of individual wells by as much as a factor of two. Controlling the chemistry of water could provide a better solution for increased heavy oil recovery instead of increasing the injected water temperature, that could lower the energy required to move the heavy oil from the heavy oil reservoirs in general and in this work for the eastern Kansas oil reservoirs. The conclusions can be drawn as follows:

1. The adsorption of the organic material in heavy crude oil on the sandstone decreased because of the rock became too waterwet for observing smart water flooding effect when the divalent cations presented in a higher concentration.

2. Heating could reduce the oil viscosity, interfacial tension, and residual oil saturation which lead to potentially higher recovery factor. Yet, controlling the chemistry of water (especially divalent cations) could improve oil recovery instead of increasing the injected water temperature. Increasing temperature with tune water concentration provide a greater heavy crude oil recovery.

\section{Acknowledgements}

The authors would like to express their grateful acknowledge to Colt Energy Company. The authors thank the Higher Committee for Education Development in Iraq and the Iraqi Ministry of Oil/ Missan Oil Company for their permission to present this paper. The authors would like to express their grateful acknowledge for Sandia National Laboratories is a multi-mission laboratory managed and operated by National Technology and Engineering Solutions of Sandia, LLC., a wholly owned subsidiary of Honeywell International, Inc., for the U.S. Department of Energy's National Nuclear Security Administration under contract DE-NA- 0003525.

\section{References}

1. Lager A, Webb KJ, Black CJ, Singleton M, Sorbie KS (2006). Low salinity oil recovery - An experimental investigation. Petrophysics 49:28-35.

2. Ligthelm D J, Gronsveld J, Hofman J, Brussee N (2009) Novel waterflooding strategy by manipulation of injection brine composition. Soc Petrol Eng J 2: 1 .

3. McGuire PL, Chatham JR, Paskvan FK (2005) Low salinity oil recovery: An exciting new EOR opportunity for Alaska \& APOS; North Slope. Soc Petrol Eng J 2: 1. 
Citation: Al-Saedi HN, Williams A, Di Torino P, Flori RE (2018) Comparison Between Cold/Hot Smart Water Flooding in Sandstone Reservoirs. J Pet Environ Biotechnol 9: 365. doi: 10.4172/2157-7463.1000365

Page 6 of 6

4. Tang G, Morrow NR (1999) Influence of brine composition and fines migration on crude oil/brine/rock interactions and oil recovery. J Pet Sci Eng 24:99-111.

5. Aksulu H, Håmsø D, Strand S, Puntervold T, Austad T (2012) Evaluation of lowsalinity enhanced oil recovery effects in sandstone: Effects of the temperature and pH gradient. Energy Fuels 26:3497-3503.

6. Austad T, Rezaeidoust A, Puntervold T (2010) Chemical mechanism of low salinity water flooding in sandstone reservoirs. Soc Petrol Eng J 2: 1.
7. Al-Saedi HN, Flori R, Brady PV (2018) Coupling low salinity water flooding and steam flooding for sandstone reservoirs; Low salinity-alternating-steam flooding (LSASF).The SPE Kingdom of Saudi Arabia: Annual Technical Symposium and Exhibition, Saudi Arabia 2: 23-26.

8. Al-Saedi, Hasan N, Brady PV, Flori RE, Heidari P (2018) Novel insights into low salinity water flooding enhanced oil recovery in sandstone: Study of the clay role. SPE Improved Oil Recovery Conference held in Tulsa, Oklahoma, USA 2: 14-18: SPE-190215-MS.

9. Ali SMF (1974) Current status of steam injection as a heavy oil recovery method. J Can Petrol Technol 13:16. 